\title{
1: 19383946-19375770
}

National Cancer Institute

\section{Source}

National Cancer Institute. 1: 19383946-19375770. NCI Thesaurus. Code C41677.

Physical location of AKR7A2_Gene 